\title{
Stage II Renal Cell Cancer AJCC v7
}

National Cancer Institute

\section{Source}

National Cancer Institute. Stage II Renal Cell Cancer A/CC V7. NCI Thesaurus. Code C89301.

Stage II includes: T2, N0, M0. T2: Lesions have been divided into T2a and T2b. T2a is defined as tumor more than $7 \mathrm{~cm}$ but less than or equal to $10 \mathrm{~cm}$ in greatest dimension, limited to the kidney. T2b is defined as tumor greater than $10 \mathrm{~cm}$, limited to the kidney. N0: No regional lymph node metastasis. M0: No distant metastasis. (AJCC 7th ed.) 